\title{
Challenges of Male Contraceptive Uptake in Indonesia: Opinion of Married Couples
}

\author{
Dian Kristiani Irawaty ${ }^{1} \&$ Maria Gayatri ${ }^{1}$ \\ ${ }^{1}$ Badan Kependudukan dan Keluarga Berencana Nasional, Jakarta, Indonesia \\ Correspondence: Dian Kristiani Irawaty, Badan Kependudukan dan Keluarga Berencana Nasional, Jakarta, \\ Indonesia. Tel: 62-811-180-7802.
}

Received: November 11, 2020

Accepted: January 26, 2021 Online Published: February 8, 2021

doi:10.5539/gjhs.v13n3p81

URL: https://doi.org/10.5539/gjhs.v13n3p81

\begin{abstract}
For more than a decade, the adoption of male contraceptive methods in Indonesia was very low compared to female methods. Yet, in some settings family planning programs focused heavily on female contraceptive services, while male contraceptive services tend to be ignorant. Information from both husbands and wives is needed to obtain an accurate understanding of contraceptive use-behavior within married-couples. Hence, the objective of this study is to investigate factors associated with male contraceptive use among Indonesian couples. This study uses the couple-matched data from the 2017 Indonesia Demographic and Health Survey (IDHS). The analytical sample included 8,427 couples. Chi-square tests and binary logistic regression models were utilized for data analysis. Findings from the bivariate and binary logistic regressions indicate that couples lived in urban areas, couples who attained secondary and higher education, couples who do not want another child, couples who discuss family planning with their spouses, and couples whose wives experienced side effect of female contraception were significantly associated with male contraceptive uptake among Indonesian couples. The results suggest that increasing male contraceptive uptake should be encouraged through spousal communication about family planning.
\end{abstract}

Keywords: male contraception, family planning, contraception uptake

\section{Introduction}

Male family planning methods are a cost-effective strategy for reducing high-risk pregnancies, decreasing unwanted pregnancies and preventing maternal and infant mortality. Despite advances in male contraceptive technology and availability, from the early 1980s up to now, contraceptive use in Indonesia has been dominated by female methods (i.e. oral pill, injections, intrauterine device, implant, tubectomy, female condom) than male methods (i.e. male condom, vasectomy, withdrawal and the rhythm method) (Central Bureau of Statistics (BPS), National Family Planning Coordinating Board, Ministry of Health, The Demographic and Health Surveys Program, \& Macro International, 1991). It is estimated that one male compared to 12 females utilize contraception in Indonesia (BKKBN, BPS, Kementerian Kesehatan RI, \& USAID, 2018). The vasectomy use remains steady at $0.2 \%$ during 2007-2017 while the male condom use had slightly increased from $1.3 \%$ in 2007 to $1.2 \%$ in 2017 (Badan Pusat Statistik, Badan Koordinasi Keluarga Berencana Nasional, Kementerian Kesehatan, \& Macro International, 2008; BKKBN et al., 2018). At the same time, the proportion of female methods utilization had increased from 55.7\% in 2007 to 55.9\% in 2017 (Badan Pusat Statistik et al., 2008; BKKBN et al., 2018).

In general, studies on contraceptive use has relied on the woman's perspective. Although some studies have investigated men's involvement in family planning decisions (Adelekan, Omoregie, \& Edoni, 2014; Clark, Yount Mon, \& Rochat, 2008; Zakaria \& Bhuiyan, 2016), the focus on women of most contraceptive studies suggests that men are not really considered to be part of the contraceptive practice (Balde et al., 2016; Le Guen, Ventola, Bohet, Moreau, \& Bajos, 2015). The perspective of men regarding family planning should also be measured not only as women's opinion but also as independent individuals with different reproductive organs, histories, and needs (Le Guen et al., 2015). Family planning surveys should interview both females and males to explore the characteristics, knowledge, attitude, and practices of family planning between two different individuals (Becker \& Costenbader, 2001; Becker, Fonseca-Becker, \& Schenck-Yglesias, 2006). Either the husband or the wife may not truly know his or her partner's sexual and family planning needs (Irani, Speizer, \& Fotso, 2014).

In order to inform the delivery of male family planning services, it is important to understand the factors and 
characteristics that contribute to a male's decision to use contraception. Some researchers argued that the place of residence may influence the male contraception services since most of the health providers tend to stay in urban areas (Ntoimo \& Chirwa-Banda, 2017; Ochako, Temmerman, Mbondo, \& Askew, 2017). The others suggest male contraceptive use depends on the couples' age (Ochako et al., 2017), the couples' educational attainment (Eeckhaut, 2018; Le Guen et al., 2015), couples' fertility preference (Ntoimo \& Chirwa-Banda, 2017), spousal communication on family planning matters (Cynthia, 2011; Shattuck et al., 2011), and side effect of female contraceptive methods (Irawaty \& Rafani, 2021).

Various studies on contraceptive behavior have been conducted in Indonesia but most have focused on a female viewpoint (Joesoef, Baughman, \& Utomo, 2015). Limited studies have given attention to couples' contraceptive behavior in Indonesia, particularly with regard to male contraceptive use. Couple data can provide a better understanding of contraceptive behavior than single data relating to one partner only (Becker, 1996). This study raised a research question: why did the adoption of male contraceptive methods in Indonesia is very low compared to female methods particularly from a married couples' perspectives in Indonesia. Hence, the objective of this study is to investigate factors associated with male contraceptive use based on the male and female viewpoints as matched-couples.

\section{Method}

\subsection{The Secondary Data}

Data are drawn from the 2017 Indonesia Demographic and Health Survey (IDHS). This survey is a nationally representative household survey in Indonesia conducted every 5 years (BKKBN et al., 2018). Based on a multi-stage stratified random sampling technique, the 2017 IDHS conducted face-to-face interviews among the ever-married women and men in the 47,963 selected households (BKKBN et al., 2018). A total of 49,627 women of reproductive age (15-49 years) participated in the survey, yielding a response rate of $97.4 \%$ (BKKBN et al., 2018). Moreover, the male participants comprised a subsample of the sampled households, with 10.009 men aged 15-54 years interviewed from every second household with a response rate of $95.9 \%$ (BKKBN et al., 2018). In the 2017 IDHS, women and men are interviewed separately in selected households, allowing the matching of partner information and analyses of couples. This study downloaded the couple-matched-dataset from the DHS program website (IDCR71FL) and weighted by male weighted variables (MV005) (USAID, 2020). The weighted sample size was all 8,925 couples who were currently married or cohabiting. The data collection and sampling procedure have been described in detail elsewhere (Croft, Marshall, \& Allen, 2018; Rutstein \& Rojas, 2006; USAID, 2012). The inclusion criteria were the selected IDHS respondents who are registered as married couples and those married respondents who have complete information on all variables of the study's interest. Furthermore, the exclusion criteria of this study were those couples who reported as pregnant or 498 couples. Thus the sample of this study was 8,427 currently married couples.

\subsection{Outcome Variable}

The outcome variable is the current use of contraceptives reported by the husband. The male respondents were also asked this question "What method are you or your partner use?" The outcome variable was classified as a binary variable of whether male respondents were currently using any male contraceptive method at the time of the survey or not. The respondents were classified as users of the male method if they were using any of the following methods: male condoms, vasectomy, withdrawal, and the rhythm method. The outcome variable was classified as users of the female method if they were using any of the following methods: oral pill, injections, intrauterine device, implant, tubectomy, or female condom.

\subsection{Key Explanatory Variables}

A number of explanatory variables have been selected on a priory studies. These include the socio-demographic characteristics of the study subjects, particularly of the couples' place of residence, couples' age, the couples' educational attainment, couples' fertility preference, spousal communication on family planning issue, and side effect of female contraceptive methods. The variable of couples' place of residence was asking the respondents whether they live in (0) urban or (1) rural areas during the survey was conducted. The couples' age difference was assessed by asking the respondents how old they were on their last birthday. The couple's age was given value (0) if both husband and wife were aged 35 or older, (1) if both husbands and wives' age were in the range of 15-34 years, and (2) if the husbands and wives were in different age groups. Another socio-demographic factor included in the analysis was the couples' educational attainment, which was assessed by asking the respondents the highest level of school they have attended (no education, primary, secondary, or above). Afterward, the couples' educational attainment was classified as (0) both secondary and higher, (1) both primary and no schooling, (3) 
different educational level.

The couples' fertility preference was assessed by asking the respondents would they like to have (another) child or would you prefer not to have anymore. The couples' fertility preference was classified as (0) both husbands and wives do not want more children, and (1) either husbands or wives or both of them want more children. Spousal communication on family planning issues was assessed by asking the male respondents if he had discussed the practice of family planning with his wife in the last six months before the survey conducted. The variable of spousal communication was classified as (0) ever communicate, and (1) never communicate. The side effect of female contraceptive methods' variable was measured by asking the female respondent whether she experienced any health problems in using a current contraceptive method (yes or no).

\subsection{Statistical Analyses}

Descriptive and bivariate statistical analyses were performed to identify the association between the dependent variable current use of contraceptive reported by the husband and the selected explanatory variables (i.e. the couples' place of residence, couples' age, the couples' educational attainment, couples' fertility preference, spousal communication on family planning issue, and side effect of female contraceptive methods). Binary logistic regression was conducted because of the dichotomy nature of the dependent variable: current contraceptive use, reported by husbands (using female contraceptive or using male contraceptives). The significance level was established at $\mathrm{p}<0.05$ with a corresponding $95 \%$ confidence interval.

\subsection{Ethical Consideration}

This study does not contain access to personal data or any confidential information. Procedures and questionnaires for 2017 IDHS survey had been reviewed and approved by the ICF International Institutional Review Board (IRB), and the survey protocols have been reviewed by the ICF IRB, the Indonesian Ministry of Health, and Badan Kependudukan dan Keluarga Berencana Nasional for the protection of human subjects, in compliance with Indonesia's laws and norms.

\section{Results}

\subsection{Characteristics of Respondents}

Table 1 set out the socio-demographic characteristics of the Indonesian couples, based on the 2017 IDHS data. Table 1 shows that the proportion of couples using female methods is much higher than male methods, $92.7 \%$ compared to $7.3 \%$. Table 1 also shows that about $51.7 \%$ of the couples live in rural areas, while $48.3 \%$ of the couples live in urban areas.

Table 1. Sample charactistics of couples in Indonesia, $2017(\mathrm{n}=8,427)$

\begin{tabular}{lll}
\hline Characteristics & $\mathbf{N}$ & $\mathbf{\%}$ \\
\hline Current contraceptive use & & \\
Female method & 7,814 & 92.7 \\
Male method & 613 & 7.3 \\
\hline Residence & & \\
Urban & 4,074 & 48.3 \\
Rural & 4,353 & 51.7 \\
\hline Couples' age & & \\
Both more than 35 years old & 4,638 & 55.0 \\
Both 15-34 years old & 1,496 & 17.8 \\
Different age groups & 2,293 & 27.2 \\
\hline Couples educational attainment & & \\
Both secondary and higher & 4,449 & 52.8 \\
Both primary and no schooling & 2,025 & 24.0 \\
Different educational level & 1,953 & 23.2 \\
\hline
\end{tabular}




\section{Couples' fertility preference}

Both not want another child $5,394 \quad 41.3$

Either one or both want another child

Spousal communication on family planning

Ever communicate

Never communicate

4,356

51.7

\section{Side effect of female contraception}

Yes

No

Source: Authors' calculation.

As revealed in Table 1, the older age groups appeared to have a higher proportion of married couples, 55\% in the age group of above 35 years, compared to $17.8 \%$ in the 15 to 24 years' age group. Moreover, only $18.9 \%$ of couples were in different age groups. Couples who attained secondary or higher education accounted for $52.8 \%$, followed by couples who attained primary education or no schooling $(24.8 \%)$. Nearly $23 \%$ of couples had different educational attainment (either secondary/higher or primary/no schooling). About $41.3 \%$ of couples did not want more children while $36 \%$ of couples want more children. Only $48.3 \%$ of couples had ever communicated about family planning with their spouses. Most of the couples had never experienced side effects of female contraception $(91.4 \%)$ and only $8.6 \%$ of couples had experienced side effects of female contraception.

Table 2. Bivariate and Logistic Regression Predicting Male Contraception Use in Indonesia, $2017(\mathrm{n}=8,427)$

\begin{tabular}{|c|c|c|c|c|c|c|}
\hline \multirow{2}{*}{ Variables } & \multirow{2}{*}{ Category } & \multicolumn{2}{|c|}{ Contraceptive use } & \multirow{2}{*}{ OR } & \multirow{2}{*}{$95 \% \mathrm{CI}$} & \multirow{2}{*}{ p-value } \\
\hline & & Female method & Male method & & & \\
\hline \multirow{2}{*}{ Place of residence } & Urban & $3,674(47,0 \%)$ & $399(65,1 \%)$ & \multirow{2}{*}{1.6} & \multirow{2}{*}{$1.3-1.9$} & \multirow{2}{*}{0.00} \\
\hline & Rural (ref) & $4,139(53,0 \%)$ & $214(34.9 \%)$ & & & \\
\hline \multirow{3}{*}{ Couples' age } & Both more than 35 years & $4,293(54.9 \%)$ & $345(56.3 \%)$ & 0.8 & $0.6-1.0$ & 0.08 \\
\hline & Both $15-34$ years & $2,145(27.5 \%)$ & $147(24.0 \%)$ & 0.8 & $0.6-1.0$ & 0.07 \\
\hline & Different age groups (ref) & $1,376(17.6 \%)$ & $121(19.7 \%)$ & \multirow{2}{*}{2.4} & \multirow{2}{*}{$1.9-3.1$} & \multirow{2}{*}{0.00} \\
\hline \multirow{3}{*}{ Couples education } & Both secondary and higher & $3,990(51.1 \%)$ & $459(74.9 \%)$ & & & \\
\hline & Both primary and no schooling & $1,956(25.0 \%)$ & $69(11.3 \%)$ & \multirow{2}{*}{0.8} & \multirow{2}{*}{$0.6-1.1$} & \multirow{2}{*}{0.13} \\
\hline & Different educational level (ref) & $1,868(23.9 \%)$ & $85(13.9 \%)$ & & & \\
\hline \multirow{2}{*}{$\begin{array}{l}\text { Couples } \\
\text { preference }\end{array}$} & Both don't want more children & $5,061(64.8 \%)$ & $333(54.3 \%)$ & \multirow[b]{2}{*}{0.6} & \multirow[b]{2}{*}{$0.5-0.7$} & \multirow[b]{2}{*}{0.00} \\
\hline & $\begin{array}{l}\text { Either one or both want more } \\
\text { children (ref) }\end{array}$ & $2,753(35.2 \%)$ & $280(45.7 \%)$ & & & \\
\hline \multirow{2}{*}{$\begin{array}{l}\text { Spousal } \\
\text { communication on } \\
\text { family planning }\end{array}$} & Yes & $3,713(47.5 \%)$ & $358(58.4 \%)$ & \multirow[b]{2}{*}{1.4} & \multirow[b]{2}{*}{$1.2-1.7$} & \multirow[b]{2}{*}{0.00} \\
\hline & No (ref) & $4,100(52.5 \%)$ & $255(41.6 \%)$ & & & \\
\hline \multirow{2}{*}{$\begin{array}{l}\text { Side effect of } \\
\text { female } \\
\text { contraception }\end{array}$} & Yes & $724(9.3 \%)$ & $4(0.7 \%)$ & \multirow{2}{*}{0.06} & \multirow{2}{*}{$0.02-0.1$} & \multirow[b]{2}{*}{0.00} \\
\hline & No (ref) & $7,090(90.7 \%)$ & $609(99.3 \%)$ & & & \\
\hline
\end{tabular}

Data presented as Odd Ratio (95\% CI). Statistically significant at $\mathrm{p}<0.05$.

The bivariate analysis on the differences between those who had used contraception, reported by the husbands, and the explanatory variables are presented below (Tables 2). Table 2 shows that the proportion of couples using male methods is much higher in urban areas than in rural areas, $65.1 \%$ compared to $34.9 \%$. The occurrence of male contraceptive adoption is higher amongst those older couples in the age group of more than 35 years rather than those couples in the age group of $15-34$ years (56.3\% compared to $24.0 \%)$. Having secondary and higher education 
levels positively correlated with adopting male methods, $74.9 \%$ compared to $11.3 \%$ of those with primary or no schooling education levels. Awareness on adopting male contraceptive methods higher among those couples who do not want any more children, compared to those couples who want more children (54.3\% to $45.7 \%)$. Those couples who discuss family planning with their spouses have a higher likelihood of adopting male contraceptive methods, $58.4 \%$ compared to $41.6 \%$. Additionally, male contraceptive use was higher among couples whose wives had never experienced side effect of female contraceptive methods compared to those couples whose wives ever experienced side effect of contraceptive methods ( $99.3 \%$ to $0.7 \%$ ). This clearly indicates that Indonesian married couples need a greater education regarding more effective modern contraceptives that are available to them.

Results of logistic regression analysis (Table 2) also indicated that respondents lived in urban areas, couples who attained secondary and higher education, couples who do not want another child, couples who discuss family planning with their spouses, and couples whose wives experienced side effect of female contraception, were predictors of adopting male contraceptive methods. Couples who attained secondary and higher education was the highest predictor (OR of 2.4) of adopting male contraceptive methods. The other confounding variable is place of residence. Couples living in urban areas were more likely to use male contraceptive methods than couples living in rural areas [1.6 (95\% CI, 1.3-1.9)]. The odds of male contraceptive use increased when both husbands and wives discussed family planning issues with each other [1.4 (95\% CI, 1.2-1.9)].

\section{Discussion}

The aim of this study was to investigate factors that influence male contraceptive use among Indonesian couples based on the 2017 IDHS. The final model of logistic regression revealed that those couples lived in urban areas, couples who attained secondary and higher education, couples who did not want another child, couples who discussed family planning with their spouses and couples whose wives experienced side effect of female contraception had higher probabilities to use male contraceptive methods than others.

The study has suggested that couples who live in urban areas are more likely to use male contraceptives methods than those couples who live in rural areas. This finding echoes similar findings from Ochako et al. (2017) in Kenya that men from rural areas were less likely to use male methods compared to their urban counterparts. Access to vasectomy and condoms are generally easier in urban areas where health clinics and pharmacies are plenty than in rural areas. Furthermore, withdrawal and periodic abstinence needs men's control during their sexual intercourse (Ortayli, Bulut, Ozugurlu, \& Çokar, 2005) is perhaps favorable among the more educated husbands (Kulczycki, 2004). In contrast, a study in Nigeria found that rural men held the negative perception that contraception is women's business which leads to a significant impact on family planning demand and uptake (Adanikin, McGrath, \& Padmadas, 2017)

Among social-economic-demographic variables, education seems to have the largest effect to male contraceptive use especially among couples who both having secondary and higher education. The large effect of education on male contraceptive adoption is associated with the role of education in empowering couples to make rational decisions and understand that it is possible to control fertility using contraceptive methods (Duze \& Mohammed, 2006). Men with higher levels of education might be more likely to encounter the dominant norm of family planning as a female business (Greene \& Biddlecom, 2000) by practicing more individual involvement in using male or cooperative contraceptive methods (Le Guen et al., 2015).

This study showed that couples who want to stop childbearing had significant association to male contraceptive use. This study confirms the findings from study of Baschieri et al. (2013) that male contraceptive use is the highest when both partners state a desire to stop childbearing. When there was disagreement between spouses on fertility desire for more children, the probability of male contraceptive use decreased significantly (Baschieri et al., 2013). However, discordance on fertility preference between spouses should not be ignored by policy makers since men's reproductive preferences and desires may constitute a major challenge to family planning program success (Bankole \& Ezeh, 1999; Ezeh, Seroussi, \& Raggers, 1996)

Furthermore, it was evidence from the findings that couples' communication in the last six months was found to be highly associated with the adoption of male contraception. Couples who communicate family planning are having greater odds to adopt a contraceptive method because there are a mutual understanding and preference regarding the decision of contraceptive method (Balde et al., 2016; Irawaty \& Pratomo, 2019). Inter-spousal communication about family planning matters also reflects the inclusion of men in family planning matters within a family and potentially negotiate reproductive choices together which leads to contraceptive adoption (Shakya et al., 2018). Couples may directly or indirectly influence each other's fertility preferences during the course of their relationship thus it may increase men's probabilities to initiate contraceptive use (Irawaty, Yasin, \& Pratomo, 2020; Yeatman \& Sennott, 2014) 
The result of this study also found that those couples whose wives experienced side effect of female contraceptive methods was significantly important in influencing male contraceptive use. Side effects of modern family planning methods, either experienced or anticipated, have been identified as a common reason that women either choose not to start or discontinue contraceptives (Schrumpf et al., 2020). Side effects of contraception include heavier menstrual bleeding (Chen et al., 2020), oligomenorrhea (He et al., 2020), obesity (Simmons \& Edelman, 2016), headaches (Hellier, 2013), and nausea (Rodriguez, Godfrey, Warden, \& Curtis, 2013). Certain side effects of female contraception will always be considered unacceptable for some women, making their husbands play a further role in family planning options (Shattuck, Perry, Packer, \& Quee, 2016; Shattuck et al., 2014). A study in Bangka Belitung Islands also confirmed the result that side effect of female contraceptive use is one of substantial factors related to male contraceptive adoption in the Islands (Irawaty \& Rafani, 2021).

This study has limitations. Firstly, 2017 IDHS did not provide information related to the perception of contraception and approval of family planning from a woman's viewpoint. Secondly, the 2017 IDHS does not provide couples' weight; therefore, the IDHS team suggested that the male-weighted variable be used to weight the data (Croft, Marshall, \& Allen, 2018). Thirdly, the 2017 IDHS consists of cross-sectional data all of which were collected during the same period.

\section{Conclusion}

To conclude, this study reveals how a couple-approach can deliver an alternative viewpoint on contraceptive use behaviors. Family planning programs need to consider the role of men in influencing contraceptive behaviors of couples. Findings from this analysis are important for reconstructing future family planning program activities that seek to engage men and bring them to the table as equal partners in contraceptive adoption and continuation. As results from this study, program activities should be tailored not just by family planning promotion but also by encouraging spousal communication on family planning issues. It is these types of couple-comprehensive programming that are likely to be the most successful in reducing unintended pregnancy and unmet need in Indonesia.

\section{Acknowledgments}

The study was supported by Badan Kependudukan dan Keluarga Berencana Nasional.

\section{Data Availability Statement}

Open access data.

\section{Competing Interests Statement}

The authors declare that there are no competing or potential conflicts of interest.

\section{References}

Adanikin, A. I., McGrath, N., \& Padmadas, S. S. (2017). Impact of men's perception on family planning demand and uptake in Nigeria. Sexual and Reproductive Healthcare, 14(2017), 55-63. https://doi.org/10.1016/j.srhc.2017.10.002

Adelekan, A., Omoregie, P., \& Edoni, E. (2014). Male involvement in family planning: Challenges and way forward. International Journal of Population Research, 2014, 1-9. https://doi.org/10.1155/2014/416457,

Badan Pusat Statistik, Badan Koordinasi Keluarga Berencana Nasional, Kementerian Kesehatan, \& Macro International. (2008). Indonesia Demographic and Health Survey (Survei Demografi dan Kesehatan Indonesia) 2007. https://doi.org/FR218

Balde, M. D., Diallo, B. A., Rachidatou, C., Bah, A. K., Ali, M., Kabra, R., \& Kouanda, S. (2016). Men's behavior surrounding use of contraceptives in Guinea. International Journal of Gynecology and Obstetrics, 135, S16-S19. https://doi.org/10.1016/j.ijgo.2016.08.007

Bankole, A., \& Ezeh, A. C. (1999). Unmet need for couples: An analytical framework and evaluation with DHS data. Population Research and Policy Review, 18(6), 579-605. https://doi.org/10.1023/A:1006373106870

Baschieri, A., Cleland, J., Floyd, S., Dube, A., Msona, A., Molesworth, A., ... \& French, N. (2013). Reproductive preferences and contraceptive use: A Comparison of monogamous and polygamous couples in Northern Malawi. J. Biosoc. Sci, 45, 145-166. https://doi.org/10.1017/S0021932012000569

Becker, S. (1996). Couples and reproductive health: A review of couple studies. Studies in Family Planning, 27(6), 291-306. https://doi.org/10.2307/2138025

Becker, S., \& Costenbader, E. (2001). Husbands' and wives' reports of contraceptive use. Studies in Family 
Planning, 32(2), 111-129. https://doi.org/10.1111/j.1728-4465.2001.00111.x.

Becker, S., Fonseca-Becker, F., \& Schenck-Yglesias, C. (2006). Husbands' and wives' reports of women's decision-making power in Western Guatemala and their effects on preventive health behaviors. Social Science and Medicine, 62(9), 2313-2326. https://doi.org/10.1016/j.socscimed.2005.10.006

BKKBN, BPS, Kementerian Kesehatan RI, \& USAID. (2018). Indonesia Demographic and Health Survey (Survei Demografi dan Kesehatan Indonesia) 2017. Jakarta: BKKBN, BPS, Kementerian Kesehatan RI dan USAID.

Central Bureau of Statistics (BPS), National Family Planning Coordinating Board, Ministry of Health, The Demographic and Health Surveys Program, \& Macro International. (1991). Indonesia Demographic and Health Survey 1991.

Chen, B. A., Eisenberg, D. L., Schreiber, C. A., Turok, D. K., Olariu, A. I., \& Creinin, M. D. (2020). Bleeding changes after levonorgestrel 52-mg intrauterine system insertion for contraception in women with self-reported heavy menstrual bleeding. Am $J$ Obstet Gynecol., 222(4S). https://doi.org/10.1016/j.ajog.2019.11.1288

Clark, J., Yount Mon, K. M., \& Rochat, R. (2008). Men's involvement in family planning in rural Bangladesh. J.Biosoc.Sci, 40, 815-840. https://doi.org/10.1017/S002193200800285X

Croft, T. N., Marshall, A. M. J., \& Allen, C. K. (2018). Guide to DHS Statistics: DHS-7. Rockville, Maryland: ICF.

Cynthia, F. L. (2011). Spousal communication and contraceptive use in rural Nepal: An event history analysis. Study in Family Planning, 42(2), 83-92. https://doi.org/10.2217/nnm.12.167

Duze, M. C., \& Mohammed, I. Z. (2006). Male knowledge, attitudes, and family planning practices in Northern Nigeria. African Journal of Reproductive Health, 10(3), 1. Retrieved from http://www.bioline.org.br/request?rh06037

Eeckhaut, M. C. W. (2018). Contraceptive sterilization: Introducing a couple perspective to examine sociodemographic differences in use. Perspect Sex Reprod Health, 49(3). https://doi.org/10.1363/psrh.12033

Ezeh, A. C., Seroussi, M., \& Raggers, H. (1996). Men's fertility, contraceptive use, and reproductive preferences. DHS Comparative Studies No. 18. https://doi.org/10.3109/00016925709169500

Greene, M. E., \& Biddlecom, A. E. (2000). Absent and problematic men: Demographic accounts of male reproductive roles. Population and Development Review, 26(1), 81-115. Retrieved from http://www.jstor.org/stable/2137833?origin=crossref

He, Y., Zheng, D., Shang, W., Wang, X., Zhao, S., Wei, Z., ... \& Qiao, J. (2020). Prevalence of oligomenorrhea among women of childbearing age in China: A large community-based study. Womens Health (Lond), 16. https://doi.org/10.1177/1745506520928617.

Hellier, S. (2013). Hormonal contraception and headaches: what are the prescriber's options? Nurse Pract, 38(12), 32-37. https://doi.org/ 10.1097/01.NPR.0000437573.68400.c1.

Irani, L., Speizer, I. S., \& Fotso, J. C. (2014). Relationship characteristics and contraceptive use among couples in urban Kenya. International Perspectives on Sexual and Reproductive Health, 40(1), 11-20. https://doi.org/10.1363/4001114

Irawaty, D. K., \& Pratomo, H. (2019). Spousal communication on family planning and contraceptive adoption in Indonesia. Indian Journal of Public Health Research \& Development, 10(3), 372-376. https://doi.org/https://doi.org/10.5958/0976-5506.2019.00521.7

Irawaty, D. K., \& Rafani, Y. (2021). Factors affect the vasectomy uptake of married couples in Bangka Belitung Islands, Indonesia. International Journal of Public Health Science (IJPHS), 10(1). https://doi.org/10.11591/ijphs.v10i1.20613

Irawaty, D., Yasin, S., \& Pratomo, H. (2020). Family planning communication between wives and husbands: Insights from the 2017 Indonesia Demographic and Health Survey. Kesmas: National Public Health Journal, 15(3). http://dx.doi.org/10.21109/kesmas.v15i3.3301

Joesoef, M. R., Baughman, A. L., \& Utomo, B. (2015). Approval of contraceptive use in Indonesia: Program implications. Studies in Family Planning, 19(3), 162-168. https://doi.org/10.2307/1966751

Kulczycki, A. (2004). The determinants of withdrawal use in Turkey: A husband's imposition or a woman's choice? Social Science and Medicine, 59(5), 1019-1033. https://doi.org/10.1016/j.socscimed.2003.12.014 
Le Guen, M., Ventola, C., Bohet, A., Moreau, C., \& Bajos, N. (2015). Men's contraceptive practices in France: Evidence of Male involvement in family planning. Contraception, 92(1), 46-54. https://doi.org/10.1016/j.contraception.2015.03.011

Ntoimo, L. F. C., \& Chirwa-Banda, P. (2017). Examining the Role of couples' characteristics in contraceptive use in Nigeria and Zambia. Afr J Reprod Health, 21(4), 93-101. https://doi.org/ 10.29063/ajrh2017/v21i4.10.

Ochako, R., Temmerman, M., Mbondo, M., \& Askew, I. (2017). Determinants of Modern contraceptive use among sexually active men in Kenya. Reproductive Health, 14(56), 1-15. https://doi.org/10.1186/s12978-017-0316-3

Ortayli, N., Bulut, A., Ozugurlu, M., \& Çokar, M. (2005). Why withdrawal? Why not withdrawal? Men's perspectives. Reproductive Health Matter, 13(25), 164-173. https://doi.org/10.1016/S0968-8080(05)25175-3

Rodriguez, M. I., Godfrey, E. M., Warden, M., \& Curtis, K. M. (2013). Prevention and management of nausea and vomiting with emergency contraception: A systematic review. Contraception, 87(5), 583-589. https://doi.org/10.1016/j.contraception.2012.09.031.

Rutstein, S. O., \& Rojas, G. (2006). Guide to DHS Statistics: Demographic and Health Surveys Methodology. Maryland.

Retrieved

from https://dhsprogram.com/pubs/pdf/DHSG1/Guide_to_DHS_Statistics_29Oct2012_DHSG1.pdf

Schrumpf, L. A., Stephens, M. J., Nsarko, N. E., Akosah, E., Baumgartner, J. N., Ohemeng-Dapaah, S., \& Watt, M. H. (2020). Side effect concerns and their impact on women's uptake of modern family planning methods in rural Ghana: A mixed methods study. BMC Womens Health, 20(1). https://doi.org/ 10.1186/s12905-020-0885-0.

Shakya, H. B., Dasgupta, A., Ghule, M., Battala, M., Saggurti, N., Donta, B., .. \& Silverman, J. A. (2018). Spousal discordance on reports of contraceptive communication, contraceptive use, and ideal family size in rural India: A cross-sectional study. BMC Women's Health, 18(1), 1-14. https://doi.org/10.1186/s12905-018-0636-7

Shattuck, D., Kerner, B., Gilles, K., Hartmann, M., Ng'ombe, T., \& Guest, G. (2011). Encouraging contraceptive uptake by motivating men to communicate about family planning: The Malawi male motivator project. American Journal of Public Health, 101(6), 1089-1095. https://doi.org/10.2105/AJPH.2010.300091

Shattuck, D., Perry, B., Packer, C., \& Quee, C. (2016). A review of 10 years of vasectomy programming and research in low-resource settings. Global Health: Science and Practice, 4(4), 647-660. https://doi.org/10.9745/GHSP-D-16-00235

Shattuck, D., Wesson, J., Nsengiyumva, T., Kagabo, L., Bristow, H., Zan, T., \& Ngabo, F. (2014). Who chooses vasectomy in Rwanda? Survey data from couples who chose vasectomy, 2010-2012. Contraception, 89(6), 564-571. https://doi.org/10.1016/j.contraception.2014.02.003

Simmons, K. B., \& Edelman, A. B. (2016). Hormonal contraception and obesity. Fertil Steril, 106(6), 1282-1288. https://doi.org/ 10.1016/j.fertnstert.2016.07.1094

USAID. (2012). DHS Sampling and Household Listing Manual. Retrieved July 20, 2020, from https://dhsprogram.com/publications/publication-dhsm4-dhs-questionnaires-and-manuals.cfm

USAID. (2020). Indonesia Demographic and Health Survey Dataset. Retrieved July 9, 2020, from https://dhsprogram.com/data/

Yeatman, S., \& Sennott, C. (2014). The relationship between partners' family-size preferences in Southern Malawi. Studies in Family Planning, 45(3), 361-377. https://doi.org/10.1111/j.1728-4465.2014.00396.x

Zakaria, M., \& Bhuiyan, M. M. (2016). Determinants of male involvement in women's reproductive health: A multilevel study in Bangladesh. Malaysian Journal of Public Health Medicine, 16(3), 211-218.

\section{Copyrights}

Copyright for this article is retained by the author(s), with first publication rights granted to the journal.

This is an open-access article distributed under the terms and conditions of the Creative Commons Attribution license (http://creativecommons.org/licenses/by/4.0/). 